\title{
Supratentorial Atypical Rhabdoid Teratoid Tumor - A Case Report
}

\section{Tumor teratoide rabdoide supratentorial atípico - relato de caso}

\author{
Paulo Moacir Mesquita Filho ${ }^{1}$ Ana Paula Pompeo Vartha ${ }^{2}$ Fernanda De Carli ${ }^{2}$ Gregori Manfroi ${ }^{2}$ \\ Marcelo Pedrotti De Cesaro ${ }^{2}$ Carlos Eduardo Bier Oro ${ }^{2}$ Vitório Ávila Figini ${ }^{3}$ \\ Nério Dutra Azambuja Júnior ${ }^{1} \quad$ Adriana Eli Beck $^{4}$ Daniela Schwingel $^{5}$ \\ ${ }^{1}$ Department of Neurosurgery, Neurology and Neurosurgery Service \\ (SNN), Hospital São Vicente de Paulo; Faculdade Meridional, \\ Academic League of SNN, Passo Fundo, RS, Brazil \\ Address for correspondence Fernanda De Carli, Medical Student, \\ Universidade de Passo Fundo, Av. Brasil Leste, 285 - São José, Passo \\ 2 Student of Medicine, Universidade de Passo Fundo, Passo Fundo, \\ RS, Brazil; Academic League of SNN, Passo Fundo, RS, Brazil \\ ${ }^{3}$ Department of Neurosurgery, Hopital São Vicente de Paulo, \\ Passo Fundo, RS, Brazil \\ 4 Pathology Institute of Passo Fundo, Department of Medicine, \\ Universidade de Passo Fundo, RS, Brazil \\ ${ }^{5}$ Pathology Institute of Passo Fundo, Department of Medicine, \\ Faculdade Meridional, Passo Fundo, RS, Brazil \\ Arq Bras Neurocir 2018;37:67-70.
}

\section{Abstract \\ Keywords \\ - atypical rhabdoid teratoid tumor \\ - embryonic tumors \\ - malignancies in childhood \\ - neuroectodermal tumors}

\section{Resumo}

\section{Palavras-chave}

- tumores teratoides rabdoides atípicos

- tumores embrionários

- malignidades em crianças

- tumores neuroectodérmicos
Atypical rhabdoid teratoid tumors (ARTTs) are rare embryonic tumors, usually localized in the posterior fossa and diagnosed in children under 3 years-old. The treatment includes surgical resection, radio and chemotherapy, and the prognostic is unfavorable, with an average median survival of 1 year. We present the case of a 3-year-old patient, with history of headache and vomiting, followed by absence seizures, temporal automatism, syncope accompanied by sialorrhea and sphincteric loss succeeded by a postictal period. Surgical excision was performed and the anatomopathological study confirmed ARTT. The ARTTs are embryonic tumors, a category in which medulloblastoma and primitive neuroectodermal tumors (PNETs) represent the most common central nervous system (CNS) malignancies in childhood.

Tumores teratóides rabdóides atípicos (TTRA) são tumores embrionários raros, geralmente localizados na fossa posterior e diagnosticados em crianças com menos de 3 anos de idade. O tratamento inclui ressecção cirúrgica, radio e quimioterapia. Contudo, o prognóstico é desfavorável, com uma sobrevida média de 1 ano. Apresentamos o caso de um paciente de 3 anos de idade, com quadro de cefaléia e vômitos, acompanhados por automatismo temporal e perda de consciência, seguidos por período pós-ictal. A ressonância nuclear magnética (RNM) do encéfalo evidenciou lesão frontal compatível com tumor intra-axial, efeito de massa local e invasão do corpo caloso. Foi realizada excisão cirúrgica, e o estudo anatômico-patológico confirmou TTRA. Os TTRA são tumores embrionários, categoria na qual o meduloblastoma e os tumores neuroectodermais primitivos representam as malignidades mais comuns no sistema nervoso central de crianças. received

November 2, 2017

accepted

December 18, 2017

published online

April 12, 2018
DOI https://doi.org/

10.1055/s-0038-1625950. ISSN 0103-5355.
Copyright $\odot 2018$ by Thieme Revinter

Publicações Ltda, Rio de Janeiro, Brazil
License terms

(요 $\Theta \circledast$ 


\section{Introduction}

The atypical rhabdoid teratoid tumor (ARTT) is a rare embryonic tumor, defined as a distinct entity in 1996 and included in the World Health Organization (WHO) classification of central nervous system (CNS) tumors in 2000. ${ }^{1-3}$ In 2016, the WHO ranked the ARTT as a CNS embryonal tumor with rhabdoid features. ${ }^{4}$ The ARTT is a highly malignant tumor whose survival period is around 1 year. This tumor is usually diagnosed in children under 3 years of age and is related with a genetic mutation that causes an inactivation of the SMARCB1 gene, losing the expression of the INI1 protein, ${ }^{2}$ a tumor suppressor. ${ }^{5}$ The authors present the case of a child patient, who showed an ARTT in the left frontal lobe, with history of 1 day of symptoms.

\section{Clinical Summary}

We present the case of a 3-year-old Caucasian male patient, with a history of headache and vomiting, followed sometimes by absence seizures, temporal automatism and syncope, accompanied by sialorrhea, sphincteric loss and postictal period. The computed tomography (CT) scan of the patient's brain revealed an expansive lesion in the left frontal lobe, hypodense, heterogeneous, with calcifications. The mass was irregular and had poorly defined borders, measuring $2.4 \times 4.8 \mathrm{~cm}$ with deviation of the midline. The magnetic resonance imaging (MRI) confirmed the left frontal lesion, with local mass effect, invasion of the corpus callosum, and irregular gadolinium enhancement and restriction to diffu- sion, suggesting a high cellular tumor ( $\mathbf{- F i g . ~ 1 a - f ) . ~ A ~ s u r g i c a l ~}$ subtotal resection was performed, and the postoperative CT scan confirmed a residual lesion ( $\mathbf{- F i g}$. $\mathbf{2 a - c}$ ).

Shortly after the initial surgery (less than 2 months), the symptoms recurred, and the new neuroimaging study confirmed tumor recrudescence. The patient was submitted to a new surgical procedure and developed meningitis due to a cerebral spinal fluid (CSF) leak, which was treated with antibiotics and intervention to the fistula. In the following months, three cycles of chemotherapy were performed, and the patient developed severe pancytopenia, acute hydrocephalus, intracranial hemorrhagic events and tumor recurrence. Due to the aggressive behavior of the tumor, as well as the poor clinical status of the patient, palliative care was undertaken.

\section{Pathological Findings}

The pathological examination evidenced a tumor with atypical elongated and polygonal cells, eosinophilic and bright cytoplasm, vesicular nuclei with not very evident nucleolus. The immunohistochemical study demonstrated inactivity of INI1 and presence of S-100 protein and $\mathrm{K}_{\mathrm{i}}-67$ (a cellular proliferation antigen). These results confirmed the diagnosis of ARTT ( - Fig. 3a-d).

\section{Discussion}

The ARTT definition originates because, histologically, tumor cells show diversity, in a combination of rhabdoid cells and
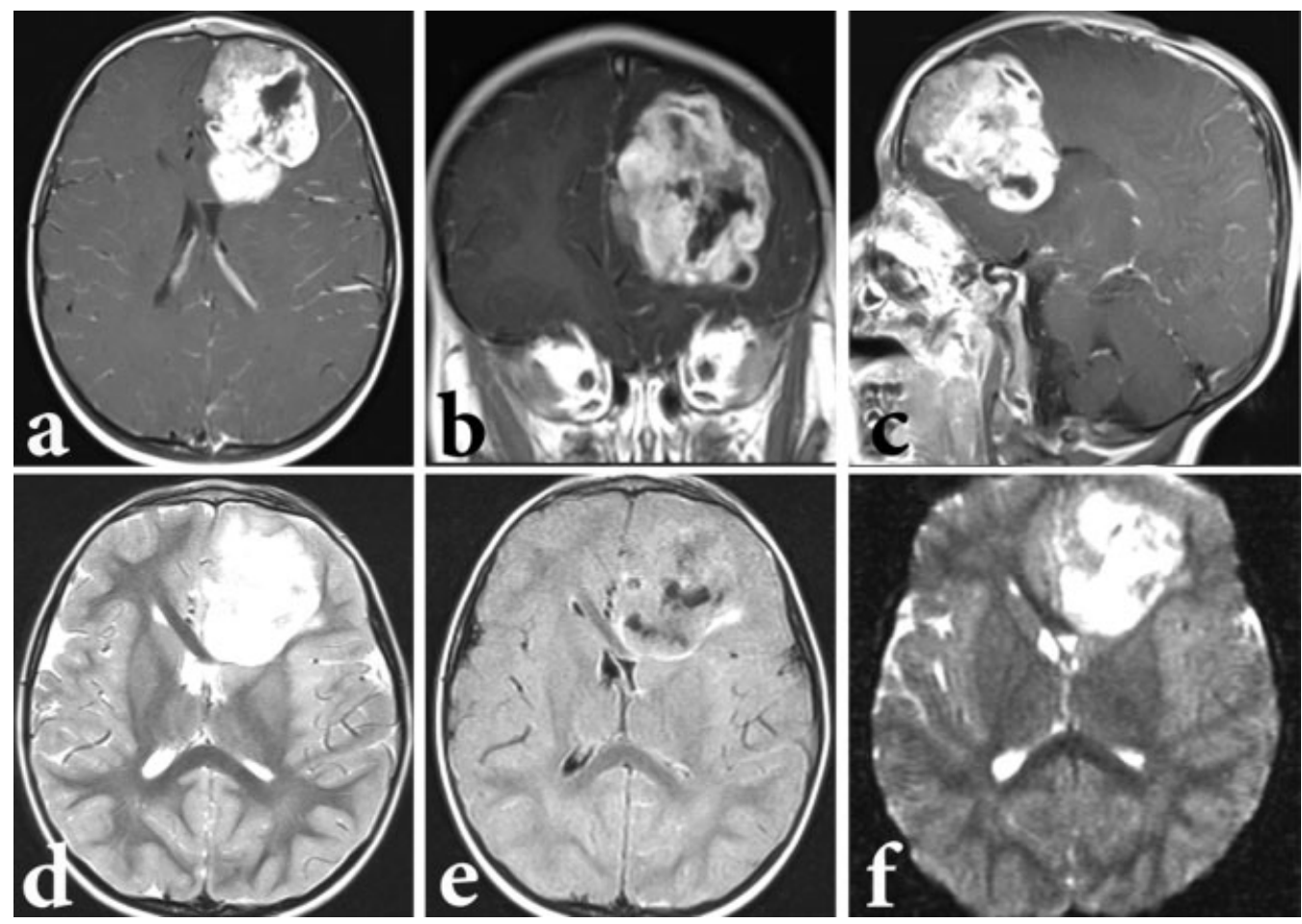

Fig. 1 MRI (a) Axial T1-Weighted with gadolinium enhancement: large intra-axial mass, with irregular contrast enhancement in the left frontal lobe extending to the frontal horn of the ipsilateral ventricle. (b) Coronal T1-Weighted with gadolinium enhancement: irregular enhancement. (c) Sagittal T1-Weighted with gadolinium enhancement: invasion of the rostrum of the corpus callosum. (d) Axial T2-Weighted: hyperintense lesion invading the corpus callosum. (e) Axial FLAIR: mild edema, besides the great diameter of the lesion. (f) Axial Diffusion Tensor: intense restriction to diffusion inside the tumor. 


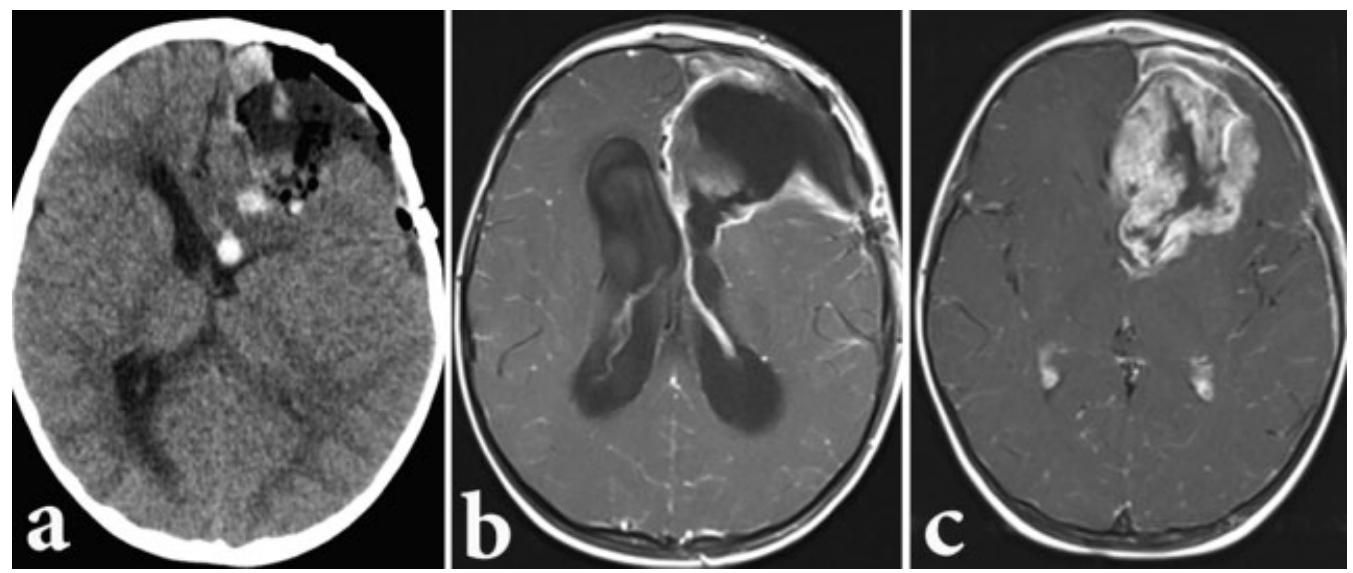

Fig. 2 (a) Immediate postoperative CT scan: subtotal resection of the tumor due to the invasion of the corpus callosum. (b) Axial T1-Weighted MRI with gadolinium enhancement: internal CSF leak, as well as intense ventricular enlargement, and gadolinium enhancement inside the ventricle and in the operative site. (c) Axial T1-Weighted MRI with gadolinium enhancement: performed 2 months after the latter, evidencing recrudesce of the lesion.

neuroectodermal, epithelial, and mesenchymal elements, but lack divergent tissue development pathognomonic of teratoma. ${ }^{1}$

The ARTT can be localized everywhere inside the CNS, including the cerebellopontine (CP) angle cisterns, meninges, cranial nerves, spinal canal and extradural sites. It can also be found outside the CNS. ${ }^{2}$ Supratentorial tumors are usually located in the cerebral hemispheres, while infratentorial lesions are more common in cerebellar hemispheres, $\mathrm{CP}$ angle and brainstem, being more prevalent in children younger than 2 years. ${ }^{4}$ The frontal lobe is commonly involved in supratentorial ARTTs, with a thick irregular heterogeneously enhancing wall encircling the central cystic or necrotic lesion. ${ }^{1}$ Tumors wider than $4 \mathrm{~cm}$ are commonly found in Caucasian male children younger than 3 years, and they normally involve the cerebellum, ventricles, or frontal lobe. ${ }^{6}$

The clinical features depend on the age of the patient, as well as on the location of the tumor. The most common symptoms include headache, vomiting, lethargy, failure to thrive, regression of developmental milestones, irritability and macrocephaly, in very young children. If the tumor involves the cerebellar hemispheres, the patient can present ataxia, head tilt and nystagmus, and if the $\mathrm{CP}$ angle is involved, the patient can also present with cranial nerve palsies. ${ }^{1}$
Brain CT scan usually demonstrates hyperdense lesion and heterogeneous contrast enhancement. Calcifications may be seen in up to $40 \%$ of tumors. Magnetic resonance imaging usually shows heterogeneous isointense signal on both $\mathrm{T} 1$ and T2-weighted images and variable enhancement with gadolinium- heterogeneous, peripheral nodular, intense, or mild. ${ }^{1}$ Embryonic tumors have similar images features. They can be iso- or hyperdense, intensifying in a homogeneous manner in the CT scan; cysts, calcifications and hemorrhage can also be found, and hydrocephalus is usually present in these patients. The MRI defines more accurately the dimension of the tumor and possible dissemination. ${ }^{7}$

Medulloblastoma is the main radiological differential diagnosis of ARTT. It may also include other embryonic tumors, such as supratentorial primitive neuroectodermal tumor, and ependymoma, teratoma, choroid plexus tumors, pilocytic astrocytoma, and desmoplastic infantile ganglioglioma. ${ }^{1}$

The main treatment for ARTTs is a combined approach, with maximal excisional surgery, radio and chemotherapy. Surgery is always performed when indicated, but, depending on the clinical status, only radiotherapy, chemotherapy or both, are performed. ${ }^{6,7}$

Histopathologic studies can evidence a tumor composed by rhabdoid cells, with cytoplasmic vacuolation and arranged in
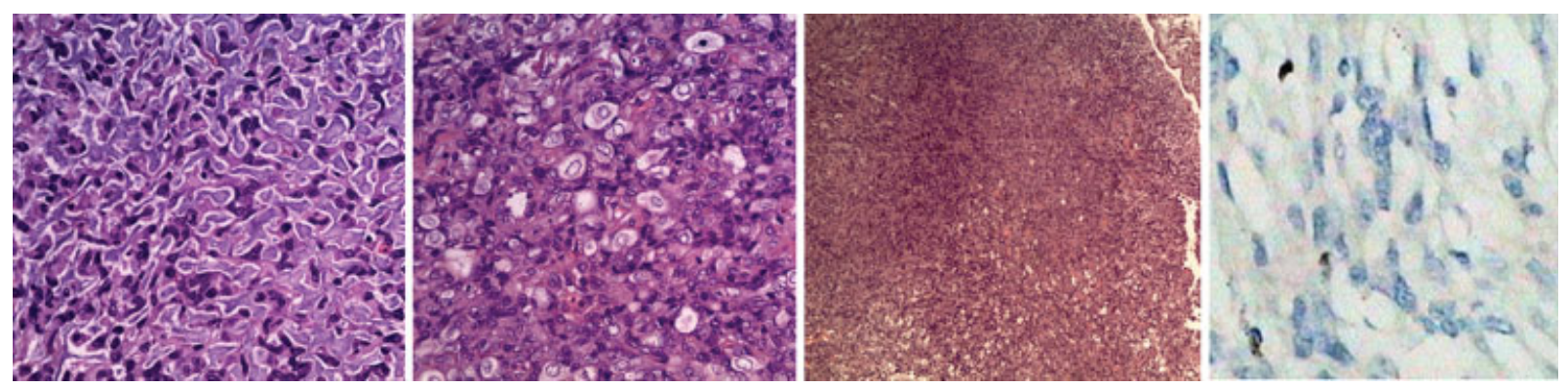

Fig. 3 (a) HE(200x). Atypical rhabdoid cells exhibiting vesicular nuclei. (b) HE(200x). Neoplastic cells sketching mucosaccharides. (c) HE (100x). Neoplastic cells with fusiform aspect. (d) Immunohistochemical study (400x) evidencing negative INI1 stain. 
nests or sheets, frequently with a jumbled appearance. However, these typical cells are found in the minority of cases. The majority of cases are formed by variable components, as primitive neuroectodermal, mesenchymal, and epithelial features. The most common components found are small-cells, mitotic figures, necrosis and hemorrhage. Mesenchymal and epithelial differentiation and myxoid matrix are less commonly found. ${ }^{4}$ Immunohistochemical stain showed that these lesions lose the nuclear expression of INI1 (a tumor suppressor gene, usually mutated in malignant rhabdoid tumors), and are positive for Vimentin, S-100 protein and epithelial membrane antigen (EMA). ${ }^{2}$ In our case, both INI1 (- Fig. 3d) and neu-N (a neuronal marker) were negative in the immunohistochemical stain, while it was positive for S-100 protein (present in cells derived from the neural crest), glial fibrillary acid protein (GFAP), typical of glial lesions, and Synaptophysin (representing neural/neuroendocrine tissues). Also, the $\mathrm{K}_{\mathrm{i}}-67$ was positive, in the order of $70 \%$. This combination was compatible with ARTT. The diagnosis of ARTT is increasing, mainly because before immunohistochemical studies, this tumor was commonly misdiagnosed, worsening the dismal prognosis of the disease. $^{2}$

This report shows the case of a young patient diagnosed with ARTT, whose clinical condition dramatically worsened within a couple of months. This demonstrates the malignant and lethal behavior of ARTT in children, despite all the efforts that can be made.

\section{Conflicts of Interest}

The authors do not have any conflict of interest.

\section{References}

1 Biswas A, Kashyap L, Kakkar A, Sarkar C, Julka PK. Atypical teratoid/rhabdoid tumors: challenges and search for solutions. [abstract]Cancer Manag Res 2016;8:115-125[serial online]

2 Oh CC, Orr BA, Bernardi B, et al. Atypical teratoid/rhabdoid tumor (ATRT) arising from the 3rd cranial nerve in infants: a clinical-radiological entity? [abstract]J Neurooncol 2015;124(02): 175-183

3 Yang M, Chen X, Wang N, et al. Primary atypical teratoid/rhabdoid tumor of central nervous system in children: a clinicopathological analysis and review of literature in China. [abstract]Int J Clin Exp Pathol 2014;7(05):2411-2420

4 Judkins AR, et al. Atypical Teratoid/Rhabdoid Tumor. In: David N. Louis et al. WHO Classification of Tumors of the Central Nervous System. 4.ed. Lyon: International Agency for Research on Cancer; 2016:209-212

5 Modena P, Sardi I, Brenca M, et al. Case report: long-term survival of an infant syndromic patient affected by atypical teratoidrhabdoid tumor. [abstract]BMC Cancer 2013;13:100

6 Lau CSM, Mahendraraj K, Chamberlain RS. Atypical teratoid rhabdoid tumors: a population-based clinical outcomes study involving 174 patients from the Surveillance, Epidemiology, and End Results database (1973-2010). Cancer Manag Res 2015; 7:301-309

7 Garvin J, Feldstein N, Ghatan S. Tumores do sistema nervoso central congênitos da infância. In: Merrit: Tratado de Neurologia. 11.ed. Rio de Janeiro: Guanabara Koogan; 2007:398-418 